\author{
AUDIT TEKNOLOGI INFORMASI PT. ASTRA \\ INTERNATIONAL, TBK (DAIHATSU) LAMPUNG \\ Erniza Dwi Wahyuni \\ $185100042 P$ \\ Fakultas Komputer \\ Ernizadwiwahyuni.student@umitra.ac.id
}

\begin{abstract}
Teknologi informasi berkembang denga cepat dan sangat berpengaruh terhadap peningkatan efisiensi serta efektivitas kegiatan bisnis dalam mengembangkan perusahaan. Dalam hal ini dibutuhkan audit teknologi informasi untuk memastikan teknologi informasi yang ada, sudah memenuhi standar kontrol umum dan memiliki kemampuan untuk bersaing dalam dunia bisnis.

Tujuan dari penelitian ini adalah mengevaluasi penilaian dan membuat rekomendasi berdasarkan analisis maturity level terhadap TI di PT. Astra International Tbk Daihatsu Lampung sesuai standar COBIT 4.1. Standar ini digunakan karena merupakan standar kontrol umum untuk pengendalian terhadap teknologi informasi dan memiliki parameter yang dapat membantu penilaian resiko suatu perusahaan dengan menggunakan maturity models.

Penelitian ini menghasilkan temuan bahwa Teknologi Informasi PT. Astra International Tbk Daihatsu Lampung dengan menggunakan kerangka kerja COBIT 4.1 memiliki maturity level sebesar 4,02. Hal ini menunjukan bahwa Teknologi Informasi yang digunakan telah dikelola dengan baik dimana prosedur dan kebijakan sudah dilakukan secara efektif, dipantau dan ada tindakan perbaikan yang segera dilakukan.
\end{abstract}

Kata Kunci : Audit teknologi informasi, maturity level, control objective for information and related technology (COBIT). 
A. PENDAhuluan

Kemajuan Teknologi Informasi yang ada sangat berpengaruh terhadap penigkatan efisiensi serta evektivitas kegiatan bisnis dalam mengembangkan perusahaan. Kegiatan akan berhasil apabila teknologi informasi bisa diselaraskan dengan kegiatan perusahaan.

PT. Astra International Tbk Daihatsu Lampung adalah perusahaan dealer mobil Daihatsu di wilayah Lampung yang buakn hanya menjual mobil ke pelanggan tetapi juga memberikan layanan servic kepada konsumen. Dalam menjalani usaha ini, teknologi informasi digunakan dalam operasional perusahaan baik dalam penjualan, servic maupun sistem HRD-nya. Teknologi informasi yang digunakan dalam perusahaan ini dibagi menjadi 2 sektor utama yaitu TI pada sektor penjualan dan sektor servic. Sektor penjualan digunakan untuk mengelola, menyiman data pelanggan. Sedangkan TI digunakan untuk menyimpan history record servic kendaraan dan menampilkan keluhan terakhir pelanggan.

PT. Astra International Tbk Daihatsu Lampung sudah cukup lama menggunakan teknologi informasi ini sebagai alat bantu dalam memberikan layanan kepada konsumen.

COBIT merupakan standar kontrol untuk pengendalian terhadap teknologi informasi. COBIT 4.1 menyediakan framework dan para 2 yang membantu penilaian resiko suatu perusahaan dengan menggunakan maturity models. Maturity Models sebagai alat ukur dalam mengetahui kondisi proses IT yang digunakan perusahaan saat ini.

B. PEMBAHASAN / STUDI KASUS

Penelitian ini menghasilkan temuan bahwa Teknologi Informasi PT. Astra International Tbk Daihatsu Lampung dengan menggunakan kerangka kerja COBIT 4.1 memiliki maturity level sebesar 4,02. Hal ini menunjukan bahwa Teknologi Informasi yang digunakan telah dikelola dengan baik dimana prosedur dan kebijakan sudah dilakukan secara efektif, dipantau dan ada tindakan perbaikan yang segera dilakukan. Karana Perusahaan PT. Astra International Tbk Daihatsu Lampung inin mewujudkan organisasi ramping, produktif dan efisiensi.

COBIT merupakan standar kontrol untuk pengendalian terhadap teknologi informasi.

\section{ID SECURITY}

QWTD4452377-ASP-5244107

\section{KESIMPULAN}

Audit Teknologi Informasi (TI) adalah mengevaluasi dan mengumpulkan bukti dari adanya sebuah sistem komputer untuk menjaga 
integritas data serta melindungi sistem komputer yang digunakan.

Berdasarkan audit 18 proses TI sesuai framework COBIT 4.1, rata-rata maturity level adalah 4,02 yang artinya TI telah dikelola dengan baik dimana prosedur dan kebijakan yang ada dlakukan secara efektif, dapat dipantau dan diukur sehingga apabila terjadi kesalahan sudah memiliki prosedur untuk tindakan perbaikan yang dilakukan.

\section{E. DISKUSI}

Saya bersama teman saya bernama Apriyan mendiskusikan tentang contoh ini dengan sangat baik Hasil diskusi dari materi ini adalah Perkembangan Teknologi Informasi yang sangat tinggi mengakibatkan perusahaan kesulitan dalam mempertahankan eksistensinya dalam jangka panjang.

Aplikasi Teknologi Informasi (TI) Merupakan bagian strategi perusahaan yang berkaitan dengan fungsi perencanaan dan pengendalian manajemen organisasi perusahaan. Penggunaan TI terhadap strategi perusahaan sangat berpengaruh sengingga TI sangat dibutuhkan.Tanpa banuan teknologi informasi yang memadai maka eksistensi perusahaan akan terancam. PT. Astra International Tbk Daihatsu Lampung sudah cukup lama menggunakan teknologi informasi ini sebagai alat bantu dalam memberikan layanan kepada konsumen

\section{F. REFERENCE}

[1] O. M. Febriani and A. S. Putra, "Sistem Informasi Monitoring Inventori Barang Pada Balai Riset Standardisasi Industri Bandar Lampung," J. Inform., vol. 13, no. 1, pp. 90-98, 2014.

[2] A. S. Putra, "Paperplain: Execution Fundamental Create Application With Borland Delphi 7.0 University Of Mitra Indonesia," 2018.

[3] A. S. Putra, "2018 Artikel Struktur Data, Audit Dan Jaringan Komputer," 2018.

[4] A. S. Putra, "ALIAS MANAGER USED IN DATABASE DESKTOP STUDI CASE DB DEMOS."

[5] A. S. Putra, "COMPREHENSIVE SET OF PROFESSIONAL FOR DISTRIBUTE COMPUTING."

[6] A. S. Putra, "DATA ORIENTED RECOGNITION IN BORLAND DELPHI 7.0."

[7] A. S. Putra, "EMBARCADERO DELPHI XE 2 IN GPUPOWERED FIREMONKEY APPLICATION."

[8] A. S. Putra, "HAK ATAS KEKAYAAN INTELEKTUAL DALAM DUNIA TEKNOLOGY BERBASIS REVOLUSI INDUSTRI 4.0.”

[9] A. S. Putra, "IMPLEMENTASI PERATURAN PERUNDANGAN UU. NO 31 TAHUN 2000 TENTANG 
DESAIN

INDUSTRI

BERBASIS INFORMATION TECHNOLOGY."

[10]

A.

$\mathrm{S}$.

Putra,

"IMPLEMENTATION OF PARADOX DBASE."

[11] A.

$\mathrm{S}$.

Putra,

"IMPLEMENTATION OF

TRADE SECRET CASE

STUDY SAMSUNG MOBILE PHONE."

[12] A

"IMPLEMENTATION

PATENT FOR APPLICATION

WEB BASED CASE STUDI

WWW. PUBLIKLAMPUNG. COM."

[13] A.

S. Putra,

"IMPLEMENTATION

SYSTEM FIRST TO INVENT IN DIGITALLY INDUSTRY."

[14] A. S. Putra, "MANUAL REPORT \& INTEGRATED DEVELOPMENT

ENVIRONMENT BORLAND DELPHI 7.0."

[15] A. S. Putra, "PATENT AS RELEVAN SUPPORT RESEARCH."

[16] A. S. Putra, "PATENT FOR RESEARCH STUDY CASE OF APPLE. Inc."

[17] A. S. Putra, "PATENT PROTECTION FOR APPLICATION INVENT."

[18] A. S. Putra, "QUICK REPORT IN PROPERTY PROGRAMMING."

[19] A. S. Putra, "REVIEW CIRCUIT LAYOUT COMPONENT

REQUIREMENT ON ASUS NOTEBOOK."

[20] A. S. Putra, "REVIEW TRADEMARK PATENT FOR
INDUSTRIAL

TECHNOLOGY BASED 4.0."

[21] A. S. Putra, "TOOLBAR COMPONENT PALLETTE IN OBJECT ORIENTED PROGRAMMING."

[22] A. S. Putra, "WORKING DIRECTORY SET FOR PARADOX 7."

[23] A. S. Putra, "ZQUERY CONNECTION

IMPLEMENTED

PROGRAMMING STUDI

CASE PT. BANK BCA Tbk."

[24] A. S. Putra, D. R. Aryanti, and I. Hartati, "Metode SAW (Simple Additive Weighting) sebagai Sistem Pendukung Keputusan Guru Berprestasi (Studi Kasus: SMK Global Surya)," in Prosiding Seminar Nasional Darmajaya, 2018, vol. 1, no. 1, pp. 85-97.

[25] A. S. Putra and O. M. Febriani, "Knowledge Management Online Application in PDAM Lampung Province," in Prosiding International conference on Information Technology and Business (ICITB), 2018, pp. 181-187.

[26] A. S. Putra, O. M. Febriani, and B. Bachry, "Implementasi Genetic Fuzzy System Untuk Mengidentifikasi Hasil Curian Kendaraan Bermotor Di Polda Lampung," SIMADA (Jurnal Sist. Inf. dan Manaj. Basis Data), vol. 1, no. 1, pp. 21-30, 2018.

[27] A. S. Putra, H. Sukri, and K. Zuhri, "Sistem Monitoring Realtime Jaringan Irigasi Desa (JIDES) Dengan Konsep Jaringan Sensor Nirkabel," 
IJEIS (Indonesian J. Electron.

Instrum. Syst., vol. 8, no. 2, pp. 221-232.

[28] D. P. Sari, O. M. Febriani, and A. S. Putra, "Perancangan Sistem Informasi SDM Berprestasi pada SD Global Surya," in Prosiding Seminar Nasional Darmajaya, 2018, vol. 1, no. 1, pp. 289-294. 